\title{
SEJARAH SENSOR FILM DI INDONESIA Masa Hindia Belanda dan Pendudukan Jepang (1916 - 1945)
}

\author{
Oleh Heru Erwantoro
}

Balai Pelestarian Sejarah dan Nilai Tradisional Bandung Jln. Cinambo No. 136 Ujungberung Bandung

Email: heruerwantoro@ymail.com

\begin{abstract}
Abstrak
Banyak persoalan di dunia perfilman Indonesia, salah satunya masalah penyensoran. Untuk menemukan akar permasalahan mengenai sensor film dilakukan penelitian sejarah dengan menggunakan metode sejarah. Dari penelitian ini didapatkan bahwa landasan (motif, tujuan, ideologi) yang berbeda yang diterapkan dalam penyensoran mengakibatkan hasil yang berbeda. Pada masa Hindia Belanda, dihasilkan film-film lokal yang bergenre Hollywood penuh dengan adegan seksual dan kekerasan. Film yang demikian itu, sebagai hasil dari politik pemerintah penjajahan Hindia Belanda yang menjadikan film sebagai media untuk merusak mentalistas rakyat Hindia Belanda. Sedangkan pada masa pendudukan Jepang, pemerintah sangat berkepentingan untuk mendapat dukungan dari masyarakat luas guna kepentingan perang melawan Sekutu. Maka, dihasilkanlah film-film dokumenter yang berbasiskan ilmu pengetahuan sebagai media propaganda yang dapat memaksimalkan mobilisasi rakyat. Kedua pemerintahan itu tidak bermaksud membangun dunia perfilman di Hindia Belanda, mereka hanya menggunakan film untuk kepentingannya masing-masing.
\end{abstract}

Kata kunci: film, sensor, genre, Belanda, Jepang.

\section{Abstract}

There are many problems in Indonesian film cinema, which one is censorship. For found to root of the censorship film problems done by history research with history method. From result of this research, we founded that different basic of motivation, goal, and ideology which applicated in censorship to result in different produc too. Era Ducth Indies, produced local films with Hollywood genre full of sexual and violence. Those films as produc from political colonial Hindia Belanda which films as media for disturbed mentality of Hindia Ducth people. Whereas era Japanese, the government needs support from the people for war winning versus America. So that, era Japanese occupation produced documenter films which siences based as propaganda media which can be maxima mobilization the people. Two of government not means to develop films sector, they use film only for interesting by self.

Keywords: film, cencor, genre, Ducth, Japanese. 


\section{A. PENDAHULUAN}

Pada awal abad XXI ini dunia perfilman di Indonesia masih diwarnai oleh berbagai persoalan yang merupakan warisan abad sebelumnya. Salah satu persoalan itu adalah masalah sensor film. Masalah sensor film di Indonesia begitu kompleks. Sebuah film yang telah lolos sensor dari proses penyensoran oleh lembaga sensor yang resmi belum tentu bisa ditayangkan di bioskop-bioskop secara "mulus". Bisa saja film itu ditentang oleh kelompokkelompok masyarakat tertentu (kelompok itu baik dari kalangan yang mewakili golongan agama, budaya, pendidik dan sebagainya) maupun dari institusi seperti pemerintah daerah dan tentara.

Ternyata yang digugat bukan hanya persoalan filmnya, tetapi juga menyangkut lembaga sensornya.

"Ketika ruang kebebasan imajinatif seseorang harus dikompromikan dan dicampuri oleh pemerintah melalui sensor film, itu berarti pemerintah turut mempengaruhi imajinasi masyarakatnya. Dengan melihat perkembangan situasi masyarakat, maka kinilah saatnya untuk membubarkan Lembaga Sensor Film (LSF) bentukan Departemen Penerangan (Deppen) dan mengembalikan sensor tersebut kepada masyarakat."

Pada masa Hindia Belanda, masuknya film telah membuat Pemerintah Hindia Belanda melakukan

1 "Bubarkan Lembaga Sensor Film" dalam Kompas, Jumat, 26 November 1999) penyensoran melalui "Ordonansi Biooscoope 1916". Penyensoran terhadap film dilakukan karena Pemerintah Hindia Belanda merasa khawatir atas pengaruh film seks dan kekerasan yang dapat mengurangi kewibawaan bangsa Barat di mata rakyat pribumi. Sejak itu sampai masa kini sensor terus diberlakukan terhadap film yang akan ditayangkan.

Dari uraian di atas maka timbullah masalah pokok dalam penelitian ini, yaitu "Bagaimana jalannya sensor film di Indonesia pada masa Pemerintahan Hindia Belanda dan Pendudukan Jepang?" Dari permasalahan pokok itu diajukan beberapa pertanyaan penelitian sebagai berikut:

1. Apa yang melatarbelakangi dilakukannya penyensoran terhadap film oleh masing-masing pemerintahan?

2. Bagaimana masing-masing pemerintahan itu melakukan penyensoran terhadap film?

3. Apa dampak dari penyensoran itu, baik terhadap dunia film maupun terhadap masyarakat umum?

Dengan demikian, penelitian ini dimaksudkan untuk mempelajari serta sedapat mungkin menemukan akar permasalahan mengenai penyensoran film di Indonesia. Fokus penelitian terhadap masalah-masalah tersebut dimaksud untuk mencari jawaban atas permasalahan yang telah dirumuskan di atas. Dari penelitian ini diharapkan dapat mengungkap pola-pola penyensoran film yang telah dilakukan di Indonesia selama kurun waktu 1916 sampai 1945. 
Sebagaimana penelitian sejarah umumnya, penelitian ini menggunakan metode sejarah. Pendapat Ernst Bernheim yang dikutip oleh Ibrahim Alfian mengatakan bahwa metode sejarah terbagi ke dalam 4 tahap, yaitu: (1) Heuristik, menghimpun bukti sejarah; (2) Kritik, menguji dan menilai bukti-bukti sejarah; (3) Interpretasi, memahami makna yang sebenarnya atas bukti-bukti sejarah yang telah dinilai itu; dan (4) Historiografi, menyajikan pemikiran-pemikiran baru berdasarkan bukti-bukti sejarah yang telah dinilai itu ke dalam bentuk tulisan (Tim Penyusun Teks Book Dirasat Islamiyyah IAIN Sunan Ampel, 1993).

\section{B. HASIL DAN BAHASAN}

\section{Sensor Film Masa Hindia Belanda}

Pemerintah kurang menaruh perhatian akan datangnya film ke Hindia Belanda. Ketidakpedulian itu bersumber dari persepsi bahwa pembuatan dan pertunjukan film merupakan suatu hal yang langsung menyangkut kepentingan penduduk pribumi, sehingga pemerintah merasa tidak perlu campur tangan. Lebih jauh lagi, di Negeri Belanda sendiri sejak semula memang tidak pernah bersibuk dengan film cerita, sebab film-film Hollywood dan Eropa senantiasa memenuhi gedung-gedung bioskop di Negeri Belanda. Kekurangan pengalaman itu turut menunjang didominasinya pembuatan film di Hindia Belanda oleh orang-orang Tionghoa (Said, 1976: 7).

Namun demikian, kepedulian itu muncul juga ketika upaya para pengusaha bioskop memberlakukan sistem pembagian kelas yang bersifat rasial di dalam pertunjukan film.
Ketentuan baru seperti yang tampak pada iklan di surat kabar Bintang Betawi tahun 1903 yang menjelaskan adanya penambahan kelas, mulai dari loge (f 2), kelas 1 (f 1), kelas 2 (f 0,50), kelas 3 (hanya untuk orang Islam dan Jawa, F 0,25).

Bagi pihak pengusaha bioskop, kebijakan itu semata-mata didorong oleh motif ekonomi. Dengan adanya penunjukan kelas 3 khusus untuk orang Islam, Jawa, dan pribumi secara keseluruhan, diharapkan kelas 2 dan 1 tidak akan kosong. Orang Eropa, Cina, dan India dengan berlakunya ketentuan itu harus membeli karcis kelas 2 ke atas. Dengan begitu, orang yang status sosialnya dan penghasilannya lebih tinggi akan membeli karcis yang lebih mahal.

Sedangkan bagi Pemerintah Hindia Belanda, kebijakan itu sejalan dengan politik kolonial Belanda. Sejak dicanangkannya "politik pemerintahan tidak langsung", pemerintah kolonial berusaha menghidupkan kembali feodalisme dengan menempatkan para bupati ke tempatnya semula. Kekuasaan tradisional para bupati diperkuat dengan memberikan simbol-simbol status dan atribut-atribut kebesaran, seperti gelar kepangkatan tradisional, tanda-tanda jasa, dan lain-lain (Hardjasaputra, 1985:11). Selain itu juga, untuk lebih menegaskan stratifikasi sosial pemerintah kolonial pun memberlakukan hukum kependudukan yang membedakan penduduk ke dalam tiga golongan, yaitu tempat teratas ditempati oleh orang Eropa, tempat kedua oleh orang Timur asing, dan tempat terbawah oleh pribumi (Paulus, 1979: 73-90).

Penciptaan iklim rasialisme ini menyebabkan adanya jurang pemisah 
antara pihak penjajah dan yang dijajah atau antara kulit putih dengan kulit coklat. Masing-masing merupakan lapisan dalam masyarakat yang benarbenar terpisah oleh undang-undang tertulis (Kartodirdjo,1990:223). Demikianlah bioskop mulai berperan sebagai instrumen rasialisme. Semangat dan jiwa rasialisme yang kental pada saat itu menyebabkan bioskop berkembang, karena dana yang masuk semakin meningkat. Orang menonton bukan semata-mata tertarik oleh film yang diputar, tetapi lebih untuk menunjukkan kedudukan dan status sosialnya.

Pemerintah kolonial merasa cukup dengan memberikan dukungan saja terhadap perkembangan bioskop di Hindia Belanda yang dianggapnya dapat dijadikan sarana penegasan perbedaan kelas. Baru kemudian kepeduliannya bertambah dengan adanya usaha pembuatan film dokumenter tentang Hindia Belanda oleh Jerman. Merasa kecolongan dan untuk menutupi rasa malu, pemerintah kolonial melalui keputusan Raja No. 40 tahun 1925 membentuk NV. 'Nederlandsch Indische Film Maatschapij' yang bertugas untuk membuat film-film dokumenter. Film-film ini melahirkan kesadaran kalau media film dapat berperan sebagai media ilmu pengetahuan.

Kepedulian itu terusik kembali ketika bioskop-bioskop memutar filmfilm yang dapat berpengaruh buruk terhadap kewibawaan orang-orang kulit putih di mata orang pribumi. Pemerintah kolonial merasa khawatir, para penonton dari kalangan pribumi yang sebagian besar masih buta huruf salah menginterpretasi film-film yang ditontonnya.
Film, seperti juga kebanyakan cerita yang dipublikasikan, senantiasa menampilkan pertentangan antara halhal yang baik dan buruk. Cerita yang positif biasanya sampai pada kesimpulan, kebaikan pasti menang melawan kejahatan. Namun, yang dilihat penonton pribumi adalah gambaran mengenai kekerasan, perceraian yang merupakan kelaziman, dan perilaku lain yang menggugah penilaian mereka terhadap budaya sendiri. Mereka tidak begitu paham bahwa film yang mereka tonton itu hendak menyatakan perceraian, ganti-ganti pasangan, dan kekerasan adalah suatu hal yang buruk dan patut dihindari. Mereka tidak paham bahwa gambaran buruk di film yang mereka tonton adalah deskripsi kejatuhan moral Barat yang disajikan secara satir, tidak dengan kebanggaan (Jauhari, 1992:16).

Pemerintah kolonial merasa khawatir film akan mengubah perilaku penduduk pribumi, tetapi yang lebih dikhawatirkan lagi ialah pandangan masyarakat jajahan terhadap diri mereka. Bioskop dan film secara tidak langsung telah membuka mata penonton pribumi akan sifat-sifat asli bangsa kulit putih. Memang film-film hasil produksi Hollywood banyak sekali memperlihatkan nuansa-nuansa di mana orang Eropa/Barat ternyata sering melakukan tindakan di luar hukum. Perhatikan bagaimana resensi majalah Filmland tahun 1923 dan 1924 yang mengatakan bahwa film FLERT merupakan film Hollywood yang penuh dengan adegan pemerkosaan. Film DRIFTING adalah film yang penuh dengan adegan kekerasan tanpa mempersoalkan hukum yang ada, kemudian film PRISCILIA DREAM 
adalah sebuah film percintaan lengkap dengan adegan seronoknya. Begitu juga dengan film THE QUEEN OF THE ROYAK merupakan film yang seluruh waktunya dipenuhi adegan percintaan vulgar.

Menurut M Syarief Arief, filmfilm tersebut memperlihatkan bagaimana orang-orang Barat yang pada ketika itu menduduki stratifikasi sosial utama dan diharuskan menjadi panutan pribumi berperilaku sadis, menyimpang dari budaya yang benar, dan berbuat seronok secara teramat vulgar. Kesan bagaimana golongan utama dalam stratifikasi sosial ketika itu, di Hindia Belanda berlaku senegatif itu, ditakut-kan akan menjadikan orang-orang pribumi sebagai mayoritas mulai tumbuh kesadaran untuk tidak lagi menganggap orang Eropa/Barat lebih dari mereka dan berhak menjadi panutan (Republika, 30 Maret 1996).

Sejalan dengan kekhawatiran/ ketakutan bahwa keberadaan dan supermasi orang Eropa itu tereliminir oleh kesan film, maka mereka mendorong pemerintah membentuk badan sensor film. Pada tahun 1916, pemerintah kolonial mengeluarkan undang-undang yang mengatur masalah film dan bioskop melalui "Ordonansi Bioscoope 1916". Ordonansi itu memberi hak pemeriksaan film oleh komisi-komisi regional yang ditunjuk oleh gubernur jenderal. Badan sensor film itu namanya adalah Komisi Sensor Film (KSF) yang didirikan di 4 kota, yaitu: di Batavia, Medan, Surabaya, dan Semarang. Pemerintah memiliki hak untuk mengangkat anggotaanggota komisi dan menetapkan ketuanya (Staatsblad van Nederlandsch Indies/ STVI, 1916, No. 227).
Bila diperhatikan secara seksama, pembentukan KSF di empat kota itu memperlihatkan dua fenomena. Pertama, kurang dilihatnya film ketika itu, sebagai sesuatu yang patut dikhawatirkan bagi kehidupan dan eksistensi kolonial di Hindia Belanda. Kedua, dengan adanya KSF di empat kota itu memperlihatkan kuatnya pemerintah daerah (di keempat kota itu) untuk menetapkan calon-calon anggota KSF. Pemerintah daerah berwenang pula untuk menetapkan kebijakan pemerintah untuk melarang diputarnya satu film tertentu. Namun demikian, bisa saja dengan alasan tertentu diputar di kota/daerah lain. Hal itulah yang memperlihatkan kuatnya pemerintah daerah/kota yang ada KSFnya (STVI No. 276, pasal 2 ayat2).

Ordonansi ini ternyata secara prinsip hanya bersifat pengawasan pada mekanisme perizinan sebelum sebuah film ditayangkan. Sedangkan mengenai film yang bagaimana yang harus diterima atau ditolak tidak diatur secara jelas, tidak ada batasan yang jelas. Selain itu, setiap anggota KSF tidak mendapatkan gaji karena tidak ada kerja profesional, maka pemerintah juga tidak dapat memaksa mereka siap menyelesaikan pemeriksaan di waktu tertentu. Akibat selanjutnya, kerja menyensor adalah kerja sambilan, dapat dibawa pulang dan diperiksa sendiri-sendiri di rumah masingmasing. Ironisnya kemudian, hasil guntingan masing-masing anggota KSF itu berbeda satu dengan yang lainnya. Akibatnya, guntingan yang paling dianggap menguntungkan pemilik film mungkin itu yang diputar. Selain itu, ada juga hal yang ironi, yaitu setiap hasil pengguntingan sensor harus dikembalikan kepada pemiliknya, dengan 
demikian dapatlah dikatakan bahwa sebenarnya pada masa itu tidak ada sensor sama sekali.

Secara tegas dikatakan oleh M. Syarief Arief (Republika, 30 Maret 1996) bahwa dengan tidak adanya batasan waktu pemeriksaan sensor serta tidak adanya gaji maka amat memungkinkan terjadinya korupsi dan kolusi yang dilakukan anggota KSF dengan pemilik film. Sedangkan sanksi tertulis hanya berupa denda sebesar F. 100 atau kurungan delapan hari penjara saja bagi mereka yang memutar film tanpa disensor.

Celah-celah inilah yang dapat dimanfaatkan oleh pengusaha bioskop, sehingga ordonansi ini tetap memberi peluang bagi bioskop untuk berkembang dan mengimpor film-film yang disukainya. Dengan demikian, Ordonansi Bioskop 1916 tidak membatasi gerak perbioskopan tetapi justru merangsang perkembangannya. Film-film yang ditayangkan lebih beragam dan juga lebih cepat sekali pun dibandingkan dengan kondisi perbioskopan di Negeri Belanda. Hampir setiap pekan ada film baru dan calon-calon penonton baru pun berdatangan, bioskop semakin semarak.

Kelonggaran yang terdapat di dalam Ordonansi Bioscoope 1916, menimbulkan persepsi pada banyak orang bahwa pemerintah kolonial tidak bermaksud untuk mengurangi dampak buruk yang ditimbulkan oleh film tetapi lebih berkepentingan dengan cukai impor dan pajak tontonan.

Isu tersebut mendorong pemerintah kolonial, yang secara psikologis terserang kewibawaannya, untuk mengadakan revisi atas Ordonansi Bioscoope 1916 lewat serangkaian pembaharuan yang tertera dalam Lembaran Negara tahun 1919 No. 337, tahun 1919 No. 742, dan tahun 1922 No. 688. Akan tetapi, masalah ketentuan-ketentuan akan batasan film yang diterima atau ditolak tetap tidak tercantum.

Dalam STVI tahun 1919 memuat adanya penambahan kuota keberadaan KSF dan setahun kemudian, KSF tidak lagi hanya ditentukan di kota-kota tertentu, namun diizinkan berdiri di kota mana saja, selama dipandang memang patut didirikan oleh penguasa setempat (STVI 1920, No. 356). Dengan adanya aturan itu, maka di daerah-daerah yang merasa dirinya potensial untuk mendirikan KSF maka berdirilah KSF itu. KSF di setiap daerah memiliki otoritas sendiri untuk memutuskan apakah daerah itu menerima atau menolak sebuah film. Bisa saja di satu daerah sebuah film dinyatakan lulus sensor namun di daerah lain ditolak karena dianggap tidak relevan dengan daerah itu (STVI 1919 No. 577, pasal 3, ayat 2). Adapun kriteria sensor yang digariskan dalam STVI 1919 No. 577, pasal 4, ayat 2 adalah lolos sensor, tidak lolos sensor, dan lolos sementara. Akan tetapi, untuk menentukan ke dalam ketiga kategori itu tidak diatur secara rinci sehingga tergantung kepada otoritas dan penafsiran setiap anggota KSF di daerahnya masing-masing.

Kebijakan pemerintah kolonial di dalam hal masuknya film-film impor yang tercermin dalam tindakan KSF dirasakan oleh para importir film dan pengusaha bioskop di seluruh Hindia Belanda sangat merugikan. Mereka pun mulai bereaksi. Pada tahun 1924, dibentuklah Persatuan Gabungan 
Importir dan Pemilik Gedung Bioskop Hindia Belanda (Universal Nieuws, 1 Mei 1924). Kemudian, mereka juga mengadakan pertemuan pada tanggal 24 Maret 1924. Pertemuan itu menghasilkan 10 usulan yang diajukan kepada Gubernur Jenderal Hindia Belanda. Adapun 10 usulan itu ialah: waktu sensor hanya 14 hari, pemeriksaan sensor dilakukan oleh seluruh anggota KSF, anggota KSF harus digaji oleh pemerintah agar profesional, KSF diharapkan menjadi lembaga formal negara, dan para pemilik film yang filmnya tidak lolos sensor diharapkan diberitahu dan kemudian diundang untuk diperlihatkan sebab-sebab filmnya tidak lolos sensor (Universal Nieuws, 1 Mei 1924).

Upaya para importir dan pengusaha bioskop itu tidak hanya berhenti sampai di situ saja. Untuk menekan pemerintah, mereka meminta Konsul Jenderal USA di Batavia untuk mewakili mereka untuk menghadap kepada gubernur jenderal dan menggolkan usulan mereka. Usaha mereka ternyata tidak sia-sia. Pemerintah kolonial akhirnya menerima usulan mereka meskipun anggota Volksraad, Schumetzer dan ketua KSF Batavia, Vrient melakukan protes (Universal Nieuws, 1 Agustus 1924).

Masalah itu baru teratasi dengan dikeluarkannya Ordonansi Film tahun 1925 yang mulai berlaku pada tanggal 1 Januari 1926. Jelas bagi kita bahwa campur tangan USA juga yang mendorong pemerintah kolonial mengeluarkan peraturan itu. Kepentingan Hollywood dan USA secara keseluruhan tidaklah dapat ditolak oleh pemerintah kolonial. Dalam ordonansi (STVI 1925, No. 466) itu komisi film yang bersifat regional diubah menjadi terpusat (sentral) bagi seluruh Hindia Belanda (hanya ada di Batavia) dan ditempatkan di bawah Departemen Binnelands Bestuur. Komisi beranggotakan 9 orang dengan seorang ketua dan seorang sekretaris. Kesembilan orang itu semuanya wanita (4 wanita Eropa, 1 wanita pribumi, 4 wanita Timur asing). Para sinology dan japanlog secara khusus bertugas memeriksa film Cina dan Jepang. Adapun hak pengangkatan komisi ini berada di tangan direktur pemerintah dalam negeri. Selain itu, film yang masuk pun harus melalui kantor bea cukai Tanjung Priok untuk diperiksa dan disensor oleh komisi. Film yang ditolak dikembalikan ke bea cukai untuk dipulangkan ke negara asal. Hanya yang lolos sensor yang diserahkan ke importir untuk diedarkan (lihat Lembaran Negara tahun 1925).

Agar anggota KSF dapat bekerja profesional, pemerintah kolonial pada tahun 1925 menyediakan anggaran sebesar F. 10.560, setiap tahun anggaran bertambah sehingga pada tahun 1933 anggaran yang disediakan sebesar F. 49.280. Gaji yang diterima seorang Ketua KSF sebesar F. 150 sebulannya, adapun gaji sekretaris sebesar F. 100 per bulannya. Mengenai honor pemeriksaan film adalah sebesar $G$. 2.50/film. Melihat anggaran yang disediakan oleh pemerintah kolonial jumlahnya cukup besar, dapatlah dikatakan bahwa kedudukan dunia perfilman di Hindia Belanda cukup kuat. Tidaklah mengherankan apabila pemerintah kolonial melakukan perubahan yang cukup radikal di bidang perfilman di dekade kedua abad ke-20 itu.

Perubahan kebijakan yang radikal itu juga dapat dilihat dengan diber- 
Patanjala Vol. 2, No. 1, Maret 2010: 1-17

lakukannya pengawasan terhadap penonton film. Kepada penonton film diberlakukan batasan usia penonton, yaitu usia 17 tahun ke atas dan 17 tahun ke bawah. Begitu juga dengan ancaman hukuman lebih diperkeras lagi. Bagi mereka yang sengaja memutar film tanpa sensor dikenakan sanksi berupa denda sebesar F. 500 atau ancaman kurungan selama 3 bulan. Begitu juga dengan guntingan hasil sensor. Bila sebelumnya hasil guntingan sensor dikembalikan kepada si pemilik film, maka setelah dikeluarkannya STVI 1925, guntingan sensor itu harus dimusnahkan.

Namun demikian, suara-suara sumbang di kalangan orang Eropa masih sering terdengar bahkan semakin keras. Surat Kabar Nieuwe Weekblad yang menyuarakan suara orang Eropa pada bulan Juli 1925 menulis analisa bahwa yang paling realistis untuk dunia perfilman kala itu bukanlah membentuk kebijakan namun membuat suatu langkah yang mampu mengeliminir persepsi orang pribumi terhadap citra orang Eropa yang terdapat di film-film buatan Hollywood ketika itu.

Kegelisahan akan pengaruh buruk film terhadap citra bangsa kulit putih tetap menjadi isu menarik seperti apa yang diungkap oleh Sir Hesketch Bell dalam bukunya yang berjudul "Foreign Colonial Administration in The Far East" yang terbit tahun 1926 berikut ini:

... dalam perjalanan di Asia, tidak satu pun manusia yang ditemui tak sependapat bahwa dampak film sangat menyedihkan bagi kewibawaan orang Eropa di Timur Jauh. Sebelum bioskop menyajikan bagian yang tidak baik dari masyarakat kulit putih, banyak bangsa kulit berwarna tidak mengetahui kejatuhan moral di kalangan tertentu dalam masyarakat Barat.

Adapun ordonansi yang lebih tegas memberikan batasan mengenai apa yang dimaksud dengan film, pertunjukan film, mekanisme sensor dan sanksi pidananya dimuat dalam Lembaran Negara No. 507 tahun 1940. Dasar tindakan komisi dalam menyensor film, antara lain, film-film yang oleh komisi dianggap bertentangan dengan keamanan umum dan susila atau alasan-alasan lain yang bagi mereka berumur di atas 17 tahun dinilai dapat menimbulkan pengaruh yang menentang dan merusak.

Ordonansi itu lebih mencerminkan persepsi pemerintah kolonial terhadap bioskop dan film. Pemerintah kolonial berpandangan bahwa film mempunyai hal-hal yang buruk yang dapat mengancam kewibawaan pemerintah (dan juga bangsa kulit putih). Oleh karena itu, di dalam ordonansi itu, komisi film diberi kewenangan dengan kriteria yang luas dan sekaligus menunjukkan bahwa pemerintah hendak turut campur tangan secara politis dalam persoalan film dan bioskop (Haris Jauhari, 1992:20).

Perjalanan sensor yang dilakukan oleh komisi film mulai menampakkan pengaruhnya di perfilman dan bioskop. Para importir dan pengusaha bioskop kecil yang terutama hidup dari film seri, begitu salah satu seri tak lolos sensor maka minat penonton untuk datang menonton 
berkurang. Banyak bioskop akhirnya gulung tikar.

Segera saja bermunculan kritik terhadap kerja komisi film dan perdebatan tentang perlu tidaknya penyensoran terhadap film. Nieuw Weekblad v.d. Cinematografie, $10 \mathrm{Juli}$ 1925 memuat artikel yang berjudul Bioscoopenieuw in Indi yang mengatakan:

... dan komisi film amat sinting pula cara kerjanya. Dia memiliki gunting besar dan menggunting dengan seenaknya saja, apa menurut dia tidak dapat diloloskan.

Yang aneh dari keadaan ini ialah bahwa film yang diperkirakan akan ditolak ternyata diloloskan, dan sebaliknya film-film yang bermanfaat untuk pengetahuan ditolak atau dirusak sedemikian rupa.

Demikian, ketika film Madame Dubbary yang menegangkan karena adegan tiang gantungnya, menjadi hambar dan mengecewakan karena seluruh bagian itu dipotong sensor. Para penonton bangsa Eropa yang menjadi target pasar film ini, enggan menonton karena bagian yang menarik dari film tersebut telah dibuang. Silang pendapat antara komisi film dengan penonton tak dapat dihindarkan. Komisi film menegaskan bahwa pemotongan adegan tiang gantung itu, dimaksudkan agar kaum pribumi tidak menyaksikan adegan keji dan sadis yang dapat merusak citra bangsa kulit putih. Namun demikian, para penonton pun tetap tidak dapat menerima bila mereka harus menjadi korban dengan menonton film yang sudah tidak menarik lagi.
Sementara polemik terus berlangsung dengan berbagai asumsinya masing-masing, pihak pengusaha bioskop mengambil terobosan guna menyelamatkan jalannya bioskop mereka. Film-film yang lolos sensor yang kadang menjadi terlalu pendek untuk diputar sebagai sebuah film cerita, digabungkan dengan film lainnya, sehingga menjadi gabungan beberapa film yang kemudian terkenal dengan sebutan "sortie".

Sortie menjadi sebuah model pertunjukan baru yang diminati banyak orang. Ia tidak menyadarkan diri pada keutuhan cerita, sebab ia merupakan bagian dari guntingan-guntingan sensor, tetapi semuanya mengetengahkan bagian-bagian yang seru dari film-film itu, seperti sejumlah adegan perkelahian disambung dengan adegan-adegan lucu, lalu diteruskan dengan adegan-adegan romantik dan seterusnya (Jauhari, 1992: 22). Sortie ini pun ternyata tidak terbatas pada film-film yang lolos sensor, melainkan juga berupa kumpulan dari adeganadegan yang justru digunting sensor.

Melihat kenyataan adanya benturan keinginan orang Eropa untuk mengurangi citra buruknya dalam film dengan kepentingan ekonomi para importir film dan pengusaha bioskop membuat pemerintah kolonial kalang kabut. Rasanya tidaklah mungkin menghilangkan benturan itu. Hal yang paling mungkin dilakukan adalah bila tidak mungkin memperbaiki citra orang Barat dalam film, maka buat juga lah citra buruk orang pribumi di dalam film.

Niat jahat itu segera direalisasikan. Pada tahun 1926, seorang Belanda bernama Heuveldorp mendirikan sebuah perusahaan film 
pertama di Hindia Belanda yang diberi nama Java Film Company di Jakarta dengan laboratoriumnya di Bandung (De Locomotif, No. 70/1926). Heuveldorp mengangkat Krugers sebagai pimpinan produksinya. Film yang diproduksi oleh mereka sasarannya bukan untuk orang Eropa tetapi semata-mata ditujukan buat orang pribumi. Film pertama yang mereka buat itu diberi judul "Loetoeng Kasaroeng”. Tentu saja film ini isinya berupa unsur kekerasan yang diperankan oleh orang pribumi, maksudnya tidak lain agar persepsi para penonton pribumi terhadap orang Eropa tidak negatif sebab ternyata orang pribumi juga mempunyai tingkah laku yang sama di dalam film.

Agar film Loetoeng Kasaroeng berpengaruh besar kepada penonton pribumi, maka para pemainnya dipilih dari kalangan yang berpengaruh dan dihormati di masyarakat, yaitu Raden Kartabrata yang berasal dari kalangan bangsawan dan berprofesi sebagai guru. Demikian pula dengan pemilihan Loetoeng Kasaroeng sebagai tema dan juga judul film, dimaksudkan bahwa mitos yang berlaku di masyarakat sebenarnya setara dan sama citranya dengan film-film Hollywood. Artinya, legenda pribumi tidak kalah negatifnya dengan daya khayal orang Barat dalam film-film Hollywood.

Pemerintah kolonial sangat serius dalam hal itu, terbukti dengan perannya di dalam membantu pembuatan film Loetoeng Kasaroeng itu. Puluhan truk dari Departemen Van de Oorlog dikirimkan untuk mengangkut peralatan ke lokasi syuting, tidak hanya itu jalan ke lokasi syuting juga diperbaiki. Dukungan $100 \%$ dari pemerintah kolonial untuk memproduksi film ber-tema lokal mendorong munculnya se-mangat produksi film di dalam negeri. Setahun setelah film Loetoeng Kasaroeng dilanjutkan dengan pem-buatan film Euis Atjih. Bukan hanya semangat membuat film yang tumbuh tetapi muncul juga perusahaan-perusahaan film. Empat tahun setelah dibuatnya film Loetoeng Kasaroeng berdirilah 8 perusahaan film di Hindia Belanda, tepatnya di Batavia dan Bandung (Archipel, No. 5 tahun 1973). Dengan adanya perusahaan-perusahaan itu, maka film-film lokal dibuat dengan tema serta penyajian yang sama dengan ciri khas film-film Hollywood, yaitu keras, sadis, penuh adegan vulgar dan cenderung ke arah pelampiasan seksual. Produksi dalam negeri itu adalah film"Si Tjonat", "Si Ronda Berlumuran Darah", "Rentjong Atjeh", "Elang Laut", "Singa Laut", "Matjan Berisik", "Terang Boelan", "AlangAlang" dan lain-lainnya.

Upaya pemerintah kolonial untuk mencitrakan penduduk pribumi sama buruknya dengan orang Barat tampaknya berhasil. Penduduk pribumi disuguhi film lokal yang aktor/aktrisnya melakukan adegan keras, sadis, vulgar, dan penuh adegan seks. Pengaruh film-film itu di kemudian hari memunculkan julukan "anak wayang" di kalangan artis film yang berkonotasi negatif, yaitu dapat "dipermainkan". Film-film pribumi itu mendapat penonton yang cukup banyak sehingga dari tahun ke tahun produksi film lokal jumlahnya meningkat. Pada tahun 1939 hanya ada 4 film yang dibuat kemudian pada tahun 1940 menjadi 13 film, dan pada tahun 1941 meningkat lagi menjadi 32 film. 
Usaha pemerintah kolonial itu semakin masif dengan pelonggaran aturan sensor oleh KSF terhadap filmfilm produksi lokal. Pada tahun 1940, keluar peraturan STVI No. 507, pasal 24 , yang menyebutkan bahwa setiap pemilik film produksi dalam negeri dapat memperbaiki bagian film yang dinyatakan tidak lolos sensor dengan kesempatan waktu selama 3 bulan, bila masih tidak lolos juga maka diberi kesempatan untuk memperbaiki lagi selama 1 bulan. Selain itu, pemerintah kolonial memberikan kesempatan yang seluas-luasnya bagi film produksi dalam negeri untuk diekspor.

Berbeda dengan sikap terhadap film dalam negeri, pemerintah berusaha mengurangi film-film impor dengan memperketat penyensoran. Batasan usia penonton bagi film-film impor sangat ketat dilakukan. Sebagai contoh untuk tahun 1941-1942, terdapat 170 buah film impor setelah disensor maka 59 film dikategorikan untuk usia 17 tahun ke atas, 80 film untuk semua usia, dan 31 film untuk usia $13-17$ tahun.

\section{Sensor Film Masa Pendudukan Jepang}

Melihat pentingnya arti film sebagai media propaganda, maka sejak awal pendudukannya pemerintah militer Jepang telah melakukan kontrol sepenuhnya atas dunia perfilman. Staf propaganda yang menyertai operasi militer, menyita seluruh perusahaan perfilman. Untuk melaksanakan kebijakan di bidang perfilman, Sendenbu pada bulan Oktober 1942 membentuk Jawa Eiga Kosha (Perusahaan Film Jawa) yang dikepalai oleh Oya Soichi (Kurasawa, 1993: 238).
Pada perkembangan selanjutnya, kerangka kebijakan di bidang perfilman didasarkan atas kerangka yang dikeluarkan pada bulan September 1942 oleh Pemerintah Tokyo. Dalam kerangka itu diputuskan bahwa pengaturan industri film di wilayahwilayah pendudukan harus diserahkan kepada dua perusahaan Jepang, yakni Niche'I (Perusahaan Film Jepang yang memproduksi film) dan Eihain perusahaan yang memonopoli distribusi film yang dibentuk pada bulan Januari 1941 atas prakarsa pemerintah. Keduanya memiliki kantor pusat yang berkedudukan di Tokyo dan hendak membuat cabangnya di Jawa, dengan tujuan agar industri perfilman di Jawa disatukan dalam jaringan besar yang membentang di seluruh wilayah lingkungan bersama Asia Timur Raya. Berdasarkan ketentuan tersebut maka Jawa Eiga Kosha dibubarkan dan terbentuklah cabang Nichiei dan Eihai di Jawa.

Terhadap perusahaan-perusahaan film swasta, pemerintah pendudukan Jepang mengambil tindakan menutup perusahaan-perusahaan film itu dan menyerahkannya kepada Nippon Eiga Sha, setelah itu barulah dibuka kembali. Java Industrial Film (JIF) dan Tan`s Film adalah dua perusahaan film yang ditutup, sedangkan Popular Film Compagnie dan Union adalah dua perusahaan film yang setelah bergabung dengan Nippon Eiga Sha kemudian dibuka kembali. Union segera memproduksi film yang berjudul "Sampaikan Salamkoe Kepada Dia" (Hastuti, 1992: 38).

Sensor terhadap film dijalankan dengan sangat ketat. Semua film dari negara musuh dilarang. Untuk mengisi kekosongan, pemerintah pendudukan 
Jepang mendatangkan film-film dari Jepang dan dari negara sekutunya. Film-film yang didatangkan dari Jepang adalah film-film yang dianggap berguna bagi kepentingan propaganda. Film-film itu biasanya, isinya jelasjelas harus berisi ajaran moral dan indroktrinasi politik yang sejalan dengan keinginan pemerintah, dan film-film itu dikatagorikan sebagai film "kokusaku eiga" (film-film kebijakan nasional). Menurut Aiko Kurasawa (1993:239) film-film kebijakan nasional itu bila ditinjau dari segi isinya dapat dibagi ke dalam 6 kategori, yaitu:

1. Film yang isinya menekankan persahabatan antara bangsa Jepang dengan bangsa-bangsa Asia serta pengajaran Jepang.

2. Film yang isinya mendorong pemujaan patriotisme dan pengabdian terhadap bangsa.

3. Film yang isinya melukiskan operasi militer dan menekankan kekuatan militer Jepang.

4. Film yang isinya menggambarkan kejahatan bangsa Barat.

5. Film yang isinya menekankan moral berdasarkan nilai-nilai Jepang, seperti; pengorbanan diri, kasih sayang ibu, penghormatan terhadap orang tua, persahabatan yang tulus, sikap kewanitaan, kerajinan, dan kesetiaan.

6. Film yang isinya menekankan peningkatan produksi dan kampanye perang lainnya.

Sedangkan jenis film yang mendapat prioritas tinggi adalah filmfilm yang termasuk ke dalam film dokumenter, film cerita, dan film-film kebudayaan. Untuk film jenis dokumenter telah mulai digarap sejak
Jawa Eiga Kosha membuka studionya di Jatinegara pada bulan September 1942 dan usaha itu dilanjutkan oleh Nichie`i. Pelaksanaan pemasokan film dokumenter dan kebudayaan dilakukan oleh Nichie 'i setiap dua minggu sekali atau sejumlah 24 film dalam setahunnya (Jawa Nenkam, hlm. 170). Film-film itu biasanya mempunyai masa putar 10-20 menit dan mengandung tema-tema propaganda.

Untuk film berita, Jawa Eiga Kosha melakukan penyuntingan sebulan sekali di bawah judul "Djawa Bahroe" dan tetap diedarkan sampai mencapai nomor kedelapan pada bulan Maret 1943. Usaha tersebut kemudian dilanjutkan oleh Nichei'I yang memulai suatu seri dua mingguan yang dinamakan "Djawa Nyusu" (Berita Film Jawa). Produksi film yang dihasilkan Nichei'I mencapai produksi yang ke-19 pada bulan September 1943, dan mulai awal 1944 film berita dibuat di bawah judul baru "Nanpo Hodo" (Jawa Nenkam, hlm. 170).

Bila film-film itu dianalisis akan tampak sifatnya yang instruktif seperti yang tampak pada unsur-unsur sebagai berikut:

1. Film-film berita yang isinya menggambarkan kegiatan-kegiatan organisasi sosial politik, latihan pemuda, peningkatan produksi, pidato para pemimpin pemerintahan dan militer, kemenangan di medan pertempuran, dan lain-lain. Dalam film-film itu fokusnya ditekankan pada upaya-upaya pengajaran moral dan teknis serta bagaimana menyebar-kan pesan-pesan pemerintah. 
2. Film-film berita yang berisi pengajaran moral dan teknis. Topik-topik yang dikemukakan ialah teknik perikanan, penanaman kapas, pembuatan keramik, pemeliharaan kesehatan, dan pengenalan tradisi Jepang.

3. Penggunaan narasi bahasa Indonesia dalam film-film berita itu lebih menekankan pada ajakanajakan perang.

Adapun mengenai film cerita diproduksi dalam jumlah yang terbatas. Tema-tema film selalu diatur oleh Sendenbu. Setelah suatu tema film telah ditentukan, seorang staf Jepang dari Nichie'I membuat kerangka ringkas ceritanya, kemudian diserahkan untuk disensor oleh Sendenbu. Setelah ceritanya lolos sensor, disusun skenario lengkap dalam bahasa Indonesia. Tidak jelas berapa banyak film cerita yang telah berhasil diproduksi selama pendudukan Jepang, yang jelas Jepang mulai memproduksi film cerita di Indonesia sejak akhir bulan Desember 1943 dengan jumlah 2-3 film dalam setahun. Film-film cerita itu dibuat dengan masa putar yang bervariasi. Ada film dengan masa putar panjang (full length) seperti film "Berdjoeang" dan "Habis Hoedjan". Ada pula yang dibuat dengan masa putar 30 menit seperti film "Mimpikoe", "Ke Seberang", "Di Menara", "Djatoeh", "Berkait", "Amat Heiho", dan "Tonari". Selain itu, juga diperkenalkan film boneka yang berjudul "Pak Kromo" dengan semboyan "awas mata-mata moesoeh" yang dibuat oleh Seseo Ono (Hastuti, 1992: 38).

Film-film yang telah diproduksi tentu saja harus dipertunjukkan kepada masyarakat, untuk itu Eihai diberi tugas di dalam pemutaran film dan distribusi film. Eihai bekerja sama dengan Sendenbu merumuskan dan menjalankan program umum dengan memanfaatkan film demi tujuan propaganda. Adapun ruang lingkup tugasnya meliputi pemilihan film yang akan diedarkan, penyebaran film ke bioskop setempat, pengelolaan seluruh gedung bioskop yang disita, dan memutar film di lapangan terbuka.

Film yang secara hati-hati diproduksi dan dipilih kemudian diedarkan ke bioskop di seluruh Jawa. Ada 117 gedung bioskop yang beroperasi secara komersial pada bulan April 1943 setelah Eihai dibentuk. Dari jumlah tersebut, 95\% dimiliki pemodal Cina. Namun demikian, setelah Jepang berkuasa, semua bioskop dikuasai oleh Jepang.

Selain gedung bioskop yang bersifat komersial, terdapat juga beberapa gedung bioskop yang dipakai untuk tujuan tertentu (Kan Po. No. 16. Maret 1944. hlm. 24), yaitu:

1. Yang dimiliki oleh Jawa Eihai dan dioperasikan semata-mata untuk propaganda, ada 35 bioskop yang terdapat di Jawa dengan rincian 23 bioskop di Jawa Barat, 3 bioskop di Jawa tengah, dan 9 bioskop di JawaTimur.

2. Yang khusus diperuntukkan bagi orang Jepang, yaitu: Gekijo di Jakarta, Ginza Gekijo di Bandung, Nippon Gekijo di Semarang, Toa Gekijo di Yogyakarta, Nippon Gekijo di Surabaya, dan Kyoei Gekijo di Malang.

3. Yang semata-mata untuk memutar film berita dan film-film kebudayaan dengan masa putar yang pendek dan pertunjukannya 
tidak ditarik bayaran, yaitu tedapat di Semarang Hodo Gekijo.

4. Yang diperuntukkan untuk pendidikan anak-anak sekolah, tidak dipungut bayaran, terdapat di Kota Jakarta gedung bioskopnya bernama Ya`eshio Gekijo.

Peraturan-peraturan yang diterapkan oleh Jawa Eihai dalam mengelola gedung bioskop menunjukkan tekad pemerintah pendudukan Jepang untuk menarik sebanyak mungkin rakyat ke gedung bioskop terutama sekali bagi kalangan bawah. Penentuan pembagian bioskop ke dalam 4 kelas dan harus menyediakan tempat duduk sebanyak $50 \%$ bagi kelas yang paling murah membuktikan hal itu.

Tentu dengan menggunakan bioskop saja tidak dapat menjangkau kalangan yang lebih luas lagi. Untuk itulah diadakan "bioskop keliling". Bioskop keliling dimaksudkan untuk mengatasi kenyataan bahwa gedunggedung bioskop yang jumlahnya tidak seberapa bila dibandingkan dengan jumlah penduduk yang ada, hanya terkonsentrasi di kota-kota besar. Menurut penelitian yang dilakukan oleh Nichie'I pada awal tahun 1942, terdapat 52 gedung bioskop yang terpusat di 7 kota besar, yaitu; 13 bioskop di Jakarta, 12 bioskop di Surabaya, 7 bioskop di Bandung, 7 bioskop di Semarang, 6 bioskop di Malang, 4 bioskop di Surakarta, dan 3 bioskop di Yogyakarta. Tampaknya tidak ada satu pun bioskop yang terdapat di pedesaan tempat sebagian besar penduduk tinggal.

Upaya penyelenggaraan bioskop keliling dimulai pada bulan Agustus 1942 dan berkembang dengan pembentukan Jawa Eihai. Kantor pusat
Eihai di Tokyo mengirim 48 operator film dan perlengkapan yang dibutuhkan ke wilayah Asia Tenggara, dalam rangka meningkatkan penyelenggaraan bios-kop keliling. Enam orang di antaranya dikirim ke Jawa. Selama 15 bulan, Jawa Eihai telah berhasil membentuk 15 tim pemutar film dan 5 pangkalan operasional bioskop keliling yang tersebar di Jakarta, Yogyakarta, Semarang, Surabaya, dan Malang.

Setiap tim terdiri atas seorang staf Jawa Eihai yang bertindak sebagai operator, seorang pegawai Sendenbu setempat, seorang penerjemah, dan seorang sopir. Mereka bersafari dari desa ke desa dengan sebuah truk dan membawa perlengkapan pertunjukan seperti proyektor film, generator, dan film $35 \mathrm{~mm}$. Pemutaran film keliling ini biasanya dilaksanakan pada masa kampanye-kampanye atau acara-acara peringatan. Di samping itu juga, sasaran penontonnya tidak terbatas pada penonton umum semata-mata, tetapi juga pada kelompok-kelompok khusus seperti romusha, buruh pabrik, dan anak-anak sekolah.

\section{PENUTUP}

Dua pemerintahan yang berbeda dengan pendekatan yang berbeda melakukan sensor terhadap film. Pemerintah Hindia Belanda membuat undang-undang penyensoran film dengan landasan mempertahankan rasialisme dan melindungi citra bangsa Eropa. Dalam praktiknya, pemberlakuan sensor terhadap filmfilm impor (film-film Hollywood) sangat ketat, meliputi memperketat ijin masuknya, menggunting, dan memberlakukan batasan usia penonton. 
Akibat dari gunting sensor itu, penonton (kebanyakan bangsa Eropa) merasa dirugikan karena film menjadi tidak utuh lagi ceritanya. Sedangkan terhadap film lokal (film-film pribumi) sensor sangat lunak. Sensor yang lemah itu, tujuan-nya agar upaya Pemerintah Hindia Belanda yang dengan sengaja mendorong produksi film lokal yang sejenis dengan film-film Hollywood tidak terganggu. Berbeda dengan Pemerintah Hindia Belanda, pemerintah pendudukan Jepang melakukan sensor film berlandaskan pada ideologi dan melihat film sebagai alat propaganda. Praktik sensor mengakibatkan semua film yang berasal dari negara musuh dilarang. Namun demikian, pada sisi yang lain, karena tuntutan memproduksi film untuk kepentingan propaganda, maka mau tidak mau pemerintah pendudukan Jepang mengajari bagaimana caranya membuat film yang baik. Bila pada masa Hindia Belanda, kaum pribumi memproduksi film-film berbau seks dan kekerasan maka pada masa pendudukan Jepang kaum pribumi memproduksi film-film dokumenter yang berbasiskan ilmu pengetahuan.

\section{DAFTAR PUSTAKA}

\section{Buku}

Ardan, S.M. 1984.

Data Perbioskopan di Indonesia.

Jakarta: Direktorat Pembinaan

Film dan Rekaman Video,

Gabungan Pengusaha Bioskop

Seluruh Indonesia dan PERFIN.

Erwantoro, Heru. 1989.

Usaha Badan Musyawarah

Perfilman Nasional dalam Menentang Intervensi Politik Partai
Komunis Indonesia di Bidang Perfilman (1964-1965). Skripsi. Bandung: Jurusan Sejarah Fakultas Sastra Universitas Padjadjaran.

. 1994.

Sejarah Perfilman Indonesia Masa Kemerdekaan 1945-1994. Bandung: Departemen Pendidikan dan Kebudayaan, Direktorat Jenderal Kebudayaan, Balai Kajian Sejarah dan Nilai Tradisional.

Hastuti, Rita. 1992.

Berjuang di Garis Belakang dalam Layar Perak: 90 Tahun Bioskop Di Indonesia; Editor Haris Jauhari. Jakarta: PT Gramedia Pustaka Utama.

Hauser, Arnold. 1982.

The Sociology of Art. Chicago and London: The University of Chicago Press.

Hewison, R. 1993.

Culture and Consensus. England, Art, and Politics Since 1940. Londong: Routledge.

Jauhari, Haris (Editor). 1992.

Layar Perak: 90 Tahun Bioskop

di Indonesia. Jakarta: PT Gramedia Pustaka Utama.

Kartodirdjo, Sartono. 1990.

Pengantar Sejarah Indonesia Baru:

Sejarah Pergerakan Nasional; Dari

Kolonialisme Sampai Nasionalisme. Jilid 2. Jakarta: PT Gramedia.

Kracauver, Sigfried. 1974.

From Caligari to Hitler: A Psychological History of The German Film. New Jersey: Princeton University Press.

Kurasawa, Aiko. 1993. 
Mobilisasi dan Kontrol. Alih Bahasa oleh Hermawan Sulistyo. Jakarta: PT Gramedia.

Kusuma Veronica dan Ignatius Haryanto. 2007.

"Sensor Film di Indonesia", dalam Ketika Sensor Tak Matimati (Penyunting Ignatius Haryanto). Jakarta: Yayasan Kalam.

Lapian, dkk. 1988.

Di Bawah Pendudukan Jepang: Kenangan Empat Puluh Dua Orang yang Mengalaminya. Jakarta: Arsip Nasional Republik Indonesia.

Notosusanto, Nugroho, dkk. 1984. Sejarah Nasional Indonesia. Jilid VI. Jakarta: Balai Pustaka.

Paul Madsen, Roy. 1973. The Impact of Film. New York: Macmillan Publishing Co.

Paulus, B.P. 1979.

Garis Besar Hukum Tata Negara Hindia Belanda. Bandung: Alumni.

Said, Salim. 1976.

Perfilman di Indonesia: Sebuah Tinjauan Historis-Sosiologis. Skripsi. Jakarta: Jurusan Sosiologi Fakultas Ilmu-Ilmu Sosial Universitas Indonesia.

Sen, Krisna. 1994.

Indonesian Cinema: Framing The New Order. London: Zed Books.

Siahaan, JE. 1983.

Usmar Ismail Mengupas Film. Jakarta: Sinar Harapan.

Surianingrat, Bayu. 1981.
Sejarah Pemerintahan di Indonesia. Jakarta: Dewaruci Press.

Tim Penyusun Teks Book Dirasat Islamiyyah IAIN Sunan Ampel. 1993. Teks Book Dirasat Islamiyyah III: Sejarah dan Kebudayaan Islam. Surabaya: Anika Bahagia.

\section{Artikel}

G. Dwipayana, "Film sebagai Instrumen untuk Mengungkap Kembali Sejarah Politik Indonesia" dalam Majalah Ilmu dan Budaya, Th. IX, No. 6 Maret 1987.

M. Sarief Arief, "Refleksi Film Indonesia: Membangun Profesionalitas Lewat Sensor (1)", Republika, 30 Maret 1996.

"Refleksi Film Indonesia: Membangun Profesionalitas Lewat Sensor (2)", Republika, 1 April 1996.

."Film Seks dan Sadis: Apa dan Mengapa? Republika, 20 Juli 1994.

Riyadi Gunawan, "Sejarah Perfilman Indonesia" Prisma No. 4. Tahun XIX. 1990. h. 22.

\section{Dokumen Resmi Tercetak}

Staatblad van Nederlandsch Indies Tahun 1916 No. 227; 1919 No. 337, 577, 742; 1920. No. 356; 1922. No. 688; 1925. No. 466; 1940. No. 507

Undang-undang Republik Indonesia No. 8 Tahun 1992 Tentang Perfilman.

Peraturan Pemerintah No. 7 Tahun 1994 tentang LSF. 
Peraturan Menteri Kebudayaan dan Jawa Nenkam, h. 168. Th. 1942 h. Pariwisata No. $\quad$ 170. Th.1942

PM.31/UM.001/MKP/05 tentang Kan Po, No. 16. h. 24. Maret 1944

LSF.

Kentjana, 15 djuni 1955

4. Surat Kabar dan Majalah

Nieuwe Weekblad, 10 Djuli 1925

Siasat, 22 Djuli 1951, Djuni 1953

Aneka, 10 Djuli 1954, 20 Djuli 1954

Sinar Harapan, 30 Mei 1965

Archipel, No. 5 Th. 1973.

Asia Raja, 16 Mei 1944

Stras News, No. 2. Th. 1951, N0. 5. Th. 1954

Bintang Betawi, 30 Nopember 1900

Budaja Djaja, No. 68. Djanuari 1974

De Film, No. 6 . 28 Februari 1919

De Locomotif, No.70. Th. 1926

Djawa Baroe, No. 8. 1 April 1943

Duta Masjarakat, 5 April 1964

Het Vanderland, 29 April 1921, 23 Mei 1921, 24 September 1921

Stras News, No. 14. Th. 1955

Sunday Courier, 25 November 1951

Terkemoeka, h. 422 . Th. 1942

Universal Nieuws, 1 Mei 1924, 1 Agustus 1924

Warta Bhakti, 24 Agustus 1964, 1 Maret 1966

Indonesia, Th. IV. No. 1-2. DjanuariFebruari. 1953 